\title{
Phylogenetic and functional gene analysis of the bacterial and archaeal communities associated with the surface microlayer of an estuary
}

\author{
Michael Cunliffe ${ }^{1}$, Hendrik Schäfer ${ }^{1}$, Emma Harrison $^{2}$, Simon Cleave ${ }^{1}$, \\ Robert Upstill-Goddard ${ }^{2}$ and J Colin Murrell ${ }^{1}$ \\ ${ }^{1}$ Department of Biological Sciences, University of Warwick, Coventry, UK and ${ }^{2}$ Ocean Research Group, \\ School of Marine Science and Technology, University of Newcastle-upon-Tyne, Newcastle-upon-Tyne, UK
}

\begin{abstract}
The surface microlayer (SML) is the thin biogenic film found at the surface of a water body. The SML is poorly understood but has been shown to be important in biogeochemical cycling and sea-air gas exchange. We sampled the SML of the Blyth estuary at two sites (salinities 21 and $31 \mathrm{psu}$ ) using $47 \mathrm{~mm}$ polycarbonate membranes. DNA was extracted from the SML and corresponding subsurface water $(0.4 \mathrm{~m}$ depth) and microbial (bacteria and archaea) community analysis was performed using denaturing gradient gel electrophoresis of 16S rRNA gene PCR amplicons. The diversity of bacterial functional genes that encode enzyme subunits for methane monooxygenase ( $p m o A$ and $m m o X$ ) and carbon monoxide dehydrogenase (coxL) was assessed using PCR, clone library construction and restriction fragment length polymorphism (RFLP) analysis. Methanotroph genes were present only in low copy numbers and pmoA was detected only in subsurface samples. Diversity of $m m o X$ genes was low and most of the clone sequences detected were similar to those of mmoX from Methylomonas spp. Interestingly, some sequences detected in the SML were different from those detected in the subsurface. RFLP analysis of coxL clone libraries indicated a high diversity of carbon monoxide (CO)-utilizing bacteria in the estuary. The habitats of the closely related coxL sequences suggest that CO-utilizing bacteria in the estuary are recruited from both marine and freshwater/terrestrial inputs. In contrast, methanotroph recruitment appears to occur solely from freshwater input into the estuary.
\end{abstract}

The ISME Journal (2008) 2, 776-789; doi:10.1038/ismej.2008.28; published online 20 March 2008

Subject Category: microbial ecology and functional diversity of natural habitats

Keywords: surface microlayer; neuston; Bacteria; Archaea; methane; carbon monoxide

\section{Introduction}

The sea surface microlayer (SML), the thin biogenic film on the surface of the ocean, provides the physical link between the sea surface and the lower atmosphere (Liss and Duce, 1997). The SML has been defined as the top 1-1000 $\mu \mathrm{m}$ (Liss and Duce, 1997) but is operationally defined by the depth sampled due to selection of sampling device used (Agogue et al., 2004). In terms of its physical, chemical and biological properties, the SML is distinct from subsurface waters even a few centimetres below (Zhang et al., 1998, 2003; Zhengbin et al., 1998). The SML is a unique ecosystem, often

Correspondence: JC Murrell, Department of Biological Sciences, University of Warwick, Gibbet Hill Road, Coventry, CV4 7AL, UK. E-mail: j.c.murrell@warwick.ac.uk

Received 14 September 2007; revised 31 January 2008; accepted 2 February 2008; published online 20 March 2008 referred to as the bacterioneuston. A recent study of the bacterial communities in the SML of the coastal North Sea showed greatly reduced diversity in the SML compared to subsurface waters (Franklin et al., 2005).

The SML has the potential to modify the exchange of climatically active trace gases between ocean and atmosphere. Gases pass through the SML via slow molecular transport; hence there may be sufficient time for significant gas uptake and/or release by the bacterioneuston. Indeed, floating box experiments in the tropical Atlantic Ocean indicated methane $\left(\mathrm{CH}_{4}\right)$ and carbon monoxide (CO) processing by the SML (Conrad and Seiler, 1988) and laboratory mesocosm experiments showed that the presence of active $\mathrm{CH}_{4}$-oxidizing bacteria in the SML significantly modified $\mathrm{CH}_{4}$ fluxes, highlighting the potential significance of the bacterioneuston in air-sea gas exchange (Upstill-Goddard et al., 2003). 
Active involvement of the bacterioneuston in the air-sea exchange of $\mathrm{CH}_{4}$ and $\mathrm{CO}$ is potentially highly relevant because both strongly influence the Earth's climate and atmospheric chemistry. $\mathrm{CH}_{4}$ accounts for $\sim 15 \%$ of enhanced greenhouse forcing (IPCC, 2001) and participates in the formation of stratospheric $\mathrm{H}_{2} \mathrm{O}$ and in photochemical reactions that regulate tropospheric concentrations of $\mathrm{OH}$ and $\mathrm{O}_{3}$ (Crutzen, 1991). CO directly impacts global $\mathrm{CH}_{4}$ via its competition for $\mathrm{OH}$ radicals, the primary tropospheric $\mathrm{CH}_{4}$ sink (Crutzen, 1991; Monson and Holland, 2001).

The tropospheric $\mathrm{CH}_{4}$ inventory is uncertain (Dlugokencky et al., 1998, 2001). The marine (microbial) source of atmospheric $\mathrm{CH}_{4}$ is believed to contribute about $2-3 \%$ of atmospheric $\mathrm{CH}_{4}$ growth (Bange et al., 1994; Lelieveld et al., 1998). However, recent data from coastal waters, especially estuaries, suggest that this could be an underestimate (Upstill-Goddard et al., 2000). Estuaries are also major contributors to the global marine source of tropospheric CO (SpringerYoung et al., 1996) via the photolysis of dissolved organic matter (Zuo and Jones, 1995).

Methanotrophic Bacteria are ubiquitous in the biosphere and have been isolated from a range of ecosystems including soils (Whittenbury et al., 1970), freshwater sediments (Auman et al., 2000) and marine environments (Holmes et al., 1995). Culture-independent studies of methanotroph diversity have relied upon probes for genes encoding subunits of particulate and soluble methane monooxygenase enzymes, pmoA and $m m o X$, respectively (Dumont and Murrell, 2005). PCR primers for pmoA and $m m o X$ have been used to analyse methanotroph diversity in a range of habitats (Costello and Lidstrom, 1999; Horz et al., 2002; Kolb et al., 2003; Hutchens et al., 2004), however, relatively few studies have considered estuarine environments (Sieburth et al., 1993; McDonald et al., 2005).

Microbial consumption may be the dominant marine CO sink (Xie et al., 2005), yet very little is known about the diversity of bacteria involved in CO utilization (King, 2003; King and Weber, 2007). The cox genes encoding carbon monoxide dehydrogenase (CODH) are placed into two distinct groups; form I and form II (King, 2003). Studies of the functional diversity of CO-oxidizing Bacteria have relied on PCR probes for the carbon monoxide dehydrogenase gene (coxL) encoding the large subunit of the enzyme (King, 2003; Dunfield and King, 2004, 2005; Cleave, 2005).

For estuaries, which may dominate global air-sea exchange of both $\mathrm{CH}_{4}$ (Upstill-Goddard et al., 2000) and CO (Stubbins, 2001), an improved understanding of community structure both in the SML and subsurface is therefore critical. The main aims of this study were to compare microbial (Bacteria and Archaea) community structure in the SML with communities present in the subsurface of Blyth estuary, located on the North Sea coast of the United
Kingdom, using a culture-independent molecularbased approach.

Previous studies have focused on functional aspects of bacterioneuston communities such as resistance traits (Mudryk, 2002; Agogue et al., 2005a) and enzyme profiles (Mudryk and Skorczewski, 2000). These studies, however, relied upon culture-dependent approaches and therefore are limited by associated culture biases. We also made a preliminary comparison of the metabolic potential in the SML (bacterioneuston) and subsurface (bacterioplankton) by analysis of diversity of bacterial functional genes that are involved in the oxidation of two globally significant trace gases $\mathrm{CH}_{4}$ and $\mathrm{CO}$.

\section{Materials and methods}

Sample site and sampling

Blyth River is a tidal estuary that feeds into the North Sea and has a small port, Blyth Harbour. Samples were collected in December 2005 using the sampling protocol as previously described (Franklin et al., 2005) from two sites; site 1 (grid reference, $55^{\circ} 08^{\prime} 14.47^{\prime \prime} \mathrm{N}: 1^{\circ} 31^{\prime} 09.91^{\prime \prime} \mathrm{N}$; salinity, $21.2 \mathrm{psu} \pm 3.1$ ) and site 2 (grid reference, $55^{\circ} 07^{\prime} 16.09^{\prime \prime} \mathrm{N}$ : $1^{\circ} 29^{\prime} 44.12^{\prime \prime} \mathrm{N}$; salinity, $\left.31.4 \mathrm{psu} \pm 0.5\right)$. Forty-seven millimetre diameter polycarbonate membranes (Millipore, Watford, UK) were placed onto the surface of the water for $10 \mathrm{~s}$ using sterile forceps (sample depth $\approx 40 \mu \mathrm{m}$ ). A total of six membranes were taken within a radius of approximately $10 \mathrm{~m}$. These samples were pooled and stored on dry ice. The subsurface was sampled by placing a presterilized $1 \mathrm{l}$ bottle $0.4 \mathrm{~m}$ below the surface and removing the lid. The subsurface water (1l) was filtered through a $0.22 \mu \mathrm{m}$ Sterivex filter (Millipore) and the filter stored on dry ice.

\section{DNA extraction}

DNA extraction from the membranes was carried out following established methods (Somerville et al., 1989; Murray et al., 1998). Reagent volumes for DNA extraction from the Sterivex filters are in parentheses: $6 \mathrm{ml}(1.6 \mathrm{ml})$ of SET lysis buffer ( $0.75 \mathrm{M}$ sucrose, $40 \mathrm{~mm}$ EDTA, $50 \mathrm{~mm}$ Tris-HCl $\mathrm{pH}$ 9) was added to each of the pooled membranes before $675 \mu \mathrm{l}(180 \mu \mathrm{l})$ of fresh lysozyme (9 mg lysozyme, $9 \mu \mathrm{l} 1 \mathrm{M}$ Tris-HCl $\mathrm{pH} 8,890 \mu \mathrm{l}$ sterile $\mathrm{H}_{2} \mathrm{O}$ ) was added to each tube before incubation for $30 \mathrm{~min}$ at $37^{\circ} \mathrm{C}$ with constant rotation. After incubation, $750 \mu \mathrm{l}(200 \mu \mathrm{l})$ of sodium dodecyl sulfate $(10 \% \mathrm{w} / \mathrm{v})$ and $206 \mu \mathrm{l}(55 \mu \mathrm{l})$ fresh proteinase K (20 mg proteinase K, $50 \mu \mathrm{l} 1 \mathrm{M}$ Tris-HCl $\mathrm{pH} 8,950 \mu \mathrm{l}$ sterile $\mathrm{H}_{2} \mathrm{O}$ ) were added followed by incubation for $2 \mathrm{~h}$ at $55^{\circ} \mathrm{C}$ with constant rotation. The lysate was then removed and placed into a fresh tube before an equal volume of phenol/chloroform/ isoamyl alcohol (25:24:1, pH 8.0) was added. The tube was then mixed gently and centrifuged for $10 \mathrm{~min}$ at $6500 \mathrm{~g}$ before being repeated. DNA was 
Table 1 PCR primer sets used in this study for analysis of microbial community structure and bacterial functional gene diversity

\begin{tabular}{|c|c|c|c|c|c|}
\hline \multirow{2}{*}{$\begin{array}{l}\text { Target group/enzyme } \\
\text { Bacteria DGGE }\end{array}$} & \multirow{2}{*}{$\begin{array}{l}\text { Gene } \\
\text { 16S rRNA }\end{array}$} & \multicolumn{2}{|c|}{ Primers } & \multirow{2}{*}{$\frac{\operatorname{Tm}\left({ }^{\circ} \mathrm{C}\right)}{65-55}$} & \multirow{2}{*}{$\begin{array}{l}\text { Reference } \\
\text { Muyzer et al. (1993) }\end{array}$} \\
\hline & & $341 \mathrm{~F}$ & $518 \mathrm{R}$ & & \\
\hline Bacteria Clone Library & 16S rRNA & $27 \mathrm{~F}$ & 1492R & 60 & Lane (1991) \\
\hline Archaea (PCR 1) & 16S rRNA & $109 \mathrm{~F}$ & $958 \mathrm{R}$ & 45 & $\begin{array}{l}\text { DeLong (1992); } \\
\text { Jurgens et al. (1997) }\end{array}$ \\
\hline Archaea (PCR 2) & 16S rRNA & $\mathrm{SA} 1 \mathrm{~F}^{\mathrm{GC}} \& \mathrm{SA} 2 \mathrm{~F}^{\mathrm{GC}}$ & PARCH519R & 53.5 & $\begin{array}{l}\text { Ovreas et al. (1997); } \\
\text { Nicol et al. (2003) }\end{array}$ \\
\hline Particulate methane monooxygenase & pmoA & $189 \mathrm{~F}$ & $661 R$ & 55 & Costello and Lidstrom (1999) \\
\hline Soluble methane monooxygenase & $\operatorname{mmoX}$ & $206 \mathrm{~F}$ & $886 \mathrm{R}$ & 61 & Hutchens et al. (2004) \\
\hline Carbon monoxide dehydrogenase & $\operatorname{cox} L$ & CODH793F & CDOH2090R & 58 & Cleave (2005) \\
\hline
\end{tabular}

Abbreviation: DGGE, denaturing gradient gel electrophoresis.

precipitated with ammonium acetate and ethanol overnight at $-20^{\circ} \mathrm{C}$.

\section{PCR and denaturing gradient gel electrophoresis} Following DNA extraction, PCR amplification of $16 \mathrm{~S}$ rRNA and functional genes was performed using primer sets listed in Table 1. For all PCRs, a total volume of $50 \mu \mathrm{l}$ was used containing $20 \mu \mathrm{M}$ dNTPs, $50 \mathrm{pmol}$ of each primer, $0.75 \mu \mathrm{l}$ (3.75 U) Taq DNA polymerase (Fermentas, Burlington, Ontario, Canada), $1.5 \mathrm{mM} \mathrm{MgCl}_{2}, 5 \mu \mathrm{l} 10 \times$ PCR buffer (Fermentas) and $\approx 30 \mathrm{ng}$ DNA. A standard PCR programme consisted of initial denaturation at $94^{\circ} \mathrm{C}$ for $5 \mathrm{~min}$ followed by 35 cycles of $95^{\circ} \mathrm{C}$ for $1 \mathrm{~min}$, annealing temperature $(\mathrm{Tm})$ varied according to primer set used (Table 1), $72{ }^{\circ} \mathrm{C} 1 \mathrm{~min}$ and a final elongation step at $72{ }^{\circ} \mathrm{C}$ for $10 \mathrm{~min}$. For denaturing gradient gel electrophoresis (DGGE) with archaeal 16S rRNA genes, a nested PCR approach was used by first using primers $109 \mathrm{~F}$ and 958R, followed by PCR with primers $\mathrm{SA} 1 \mathrm{~F}^{\mathrm{GC}} / \mathrm{SA} 2 \mathrm{~F}^{\mathrm{GC}}$ and PARCH519R (Table 1). DGGE was performed with a Dcode gel system (Biorad, Hercules, CA, USA) with minor modifications of the method of Cunliffe and Kertesz (2006). Gels were prepared with acrylamide/bisacrylamide in $1 \times$ Tris-acetate-EDTA buffer with denaturant to yield a linear gradient gel containing 30-70\% denaturant, with a $0 \%$ stacking gel. The gel was run in $1 \times$ Tris-acetate-EDTA buffer at $60^{\circ} \mathrm{C}$ for a total of 1008 volt hours (constant voltage $63 \mathrm{~V}, 16 \mathrm{~h}$ ). Gels were stained with SYBR Green nucleic acid stain (Invitrogen, Paisley, UK) before the image was captured on an FLA-5000 imaging system (Fuji Film). Bacterial and archaeal DGGE profiles were compared using GelCompareII (Applied Maths, Sint-Martens-Latem, Belgium). A similarity coefficient was calculated using a curve-based Pearson correlation before constructing an UPGMA dendrogram.

Two consecutive rounds of PCR were used for pmoA and mmoX genes. One microliter of PCR product from the first round was used as template DNA for a second round of PCR $(2 \times 35$ cycles $)$. PCR products were analysed by running $5 \mu \mathrm{l}$ of PCR product on a $1.2 \%(\mathrm{w} / \mathrm{v})$ agarose gel containing ethidium bromide.
Bacterial 16S rRNA gene and functional gene clone library construction and coverage estimation

PCR amplification products from bacterial 16S rRNA gene (PCR primer set 27F and 1492R), bacterial functional genes $m m o X$ and $\operatorname{cox} L$ from site 2 were cloned using the TOPO TA cloning kit (Invitrogen) as per the manufacturer's instructions. Clone libraries were created from pooled replicate PCRs to avoid bias in library construction. Clones (24 clones per library) were screened using restriction fragment length polymorphism (RFLP) analysis of inserts digested with restriction endonucleases EcoRI/RsaI. DNA fragments were resolved by electrophoresis through a $2 \%(\mathrm{w} / \mathrm{v})$ agarose gel before each clone was assigned to an operational taxonomic unit (OTU). Evaluation of mmoX and coxL gene clone libraries was performed by repeated calculation of a nonparametric richness estimator, $S_{\text {Chao1 }}$, along an increasing number of inserts sampled for RFLP. $S_{\text {Chao } 1}$ is calculated as:

$$
S_{\text {Chao1 }}=S_{\text {obs }}+\frac{F_{1}^{2}}{2\left(F_{2}+1\right)}-\frac{F_{1} F_{2}}{2\left(F_{2}+1\right)^{2}}
$$

where $S_{\text {obs }}$ is the number of functional gene OTUs observed in the library, $F_{1}$ and $F_{2}$ are the numbers of OTUs occurring once or twice. This calculation creates an estimate of the probable total number of OTUs present in a given sample and therefore source community (Lee and Chao, 1994). When the estimator becomes asymptotic, the library is considered large enough to cover all OTUs present. Sequences (500-600 bp) of selected clones for $16 \mathrm{~S}$ rRNA genes, $p m o A, m m o X$ and $c o x L$ were obtained using the University of Warwick Central Molecular Biology Services Laboratory. Sequences from the NCBI database that were closely related to clone sequences and excised DGGE sequences in this study were identified by ARB (Ludwig et al., 1998) and Basic Local Alignment Search Tool (Altschul et al., 1990). Partial sequences of $16 \mathrm{~S}$ rRNA were imported into an ARB database (Ludwig et al., 1998) and pre-aligned against the closest relative and alignments were manually checked for consistency and valid secondary structure. The dendrogram was derived using maximum likelihood (Axml in ARB) based on alignment columns corresponding to Escherichia coli positions 166-625. Partial gene 
sequences encoding the $\alpha$ subunit of soluble $\mathrm{mmoX}$ and the large subunit of coxL were imported into ARB databases of known orthologues, translated in silico and the protein sequences were aligned using CLUSTALX. Phylogenetic dendrograms of MmoX and CoxL were constructed using distance methods in ARB and the PAM Dayhoff matrix. For MmoX dendrogram calculation, the sequence of Pseudomonas butanovora soluble butane monooxygenase $\alpha$ subunit was used as a filter, the input mask corresponded to the amino-acid positions 93-236 of MmoX of Methylococcus capsulatus (Bath). For CoxL, the sequence of Oligotropha carboxydohydrogena CoxL (positions 295-459) was used as filter. Scale bars in dendrograms indicate an estimated $10 \%$ evolutionary divergence. Bootstrapping analyses (100 replicates) were carried out using programs from the PHYLIP package (Felsenstein, 1993), SEQBOOT, PROTDIST (for MmoX and CoxL) or DNADIST (for 16S rRNA sequences), NEIGHBOR and CONSENSE. Only values higher than $75 \%$ are shown in dendrograms. Values of $75-95 \%$ are indicated as a white circle, values above $95 \%$ are shown as a solid circle on the corresponding node.

The gene sequences retrieved in this study are available under the following accession numbers: bacterial 16S rRNA gene clone sequences, DGGE band sequences and archaeal 16S rRNA gene DGGE band sequences EU340035 to EU340075; pmoA gene sequences EU419955 to EU419957; mmoX gene sequences EU371925 to EU371932; and coxL sequences EU503130 to EU503138 in GenBank.

\section{Results}

Microbial community structure and diversity

In this study, we made a comparison of the microbial communities in the SML and subsurface at two sites along a small tidal estuary using DGGE. DNA was extracted and community composition determined by analysing bacterial and archaeal 16S rRNA gene PCR amplicons (Table 1). DGGE profiles revealed that microbial community composition remained relatively similar (similarity $88 \%$ ) in subsurface waters at both sample sites (Figures 1a and b), even though salinity increased from 21 to 31 psu (a salinity of $1 \equiv 1 \mathrm{~g}$ sea salt in $1 \mathrm{~kg}$ of water) between the two sites. Many of the dominant 16S rRNA gene amplicons, present as intense bands in subsurface DGGE profiles, were also present in DGGE profiles of $16 \mathrm{~S}$ rRNA genes from the SML. Here we infer that 16S rRNA gene amplicons, which are dominant DGGE bands, are also dominant taxa in the sample taken and therefore represent abundant taxa in the community. However, several amplicons detected in the DGGE profiles from the SML were not present in subsurface profiles, indicating SML-specific microbial populations (Figure 1a).

A total of four dominant bacterial 16S rRNA gene amplicons present only in the SML at site 2 were excised and sequenced (Figure 1a). The partial 16S rRNA gene sequences obtained revealed that these genes were similar to the sequences of $16 \mathrm{~S}$ rRNA from known Betaproteobacteria, Gammaproteobacteria and Bacteriodetes retrieved from a range of marine and estuarine habitats (Table 2). A dominant amplicon present in the SML (BAC-DGGE-6) was also dominant in the subsurface and was closely affiliated (98\% sequence identity) to known Glaciecola spp. (Gammaproteobacteria, Alteromonadales) (Tolli, 2003).

Restriction fragment length polymorphism analysis of bacterial 16S rRNA gene clone libraries (50 clones per library) from site 2 for both subsurface
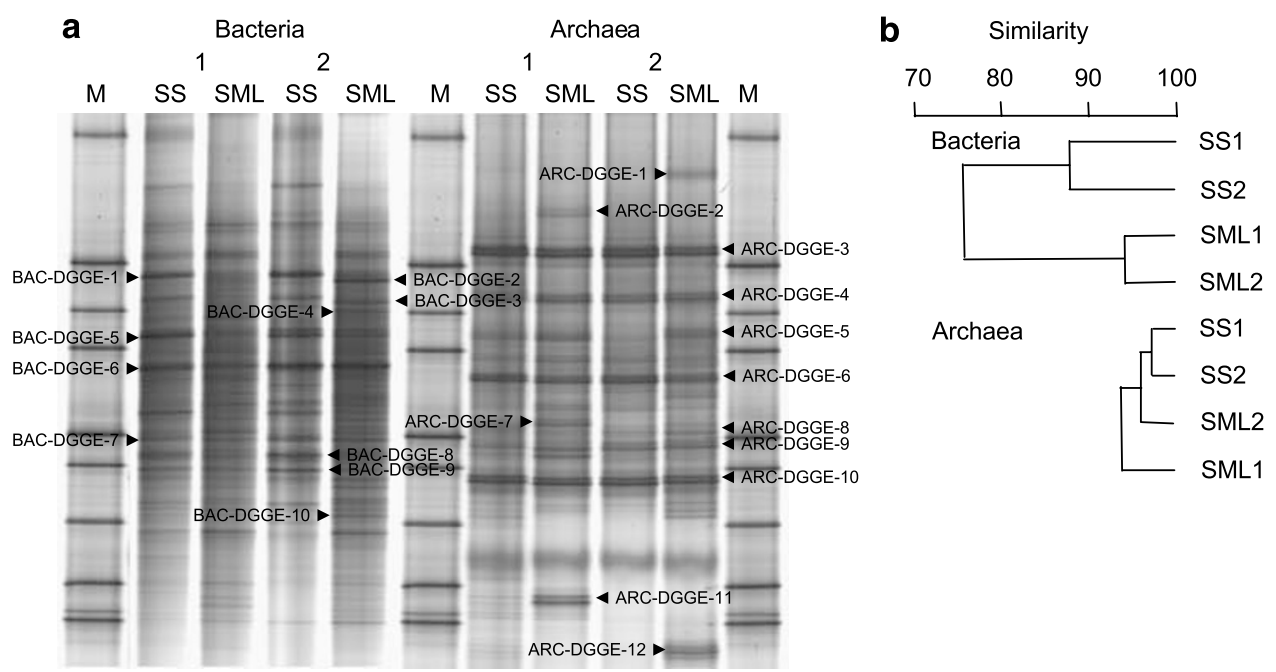

Figure 1 (a) Denaturing gradient gel electrophoresis (DGGE) profiles of archaeal and bacterial 16S rRNA gene PCR amplicons showing microbial community structure in the surface microlayer (SML) and subsurface (SS) of two sites (site 1, salinity 21 and site 2, salinity 31) along the Blyth estuary. $\mathrm{M}$ is a DGGE marker created from a bacterial 16S rRNA clone library. The highlighted DGGE bands are those which were excised and sequenced (Table 1). (b) Dendrogram showing similarity of DGGE profiles. 
Table 2 Phylogenetic affiliations of bacterial (BAC) and archaeal (ARC) 16S rRNA gene sequences obtained from Blyth River estuary surface microlayer and subsurface DNA samples after DGGE (Figure 1)

\begin{tabular}{|c|c|c|c|c|c|c|}
\hline & $D G G E$ band & $\begin{array}{l}\text { Closest BLAST } \\
\text { match (accession no.) }\end{array}$ & $\begin{array}{l}\text { Identity } \\
(\%)\end{array}$ & Habitat & Taxon & Reference \\
\hline \multirow[t]{4}{*}{$\begin{array}{l}\text { Surface } \\
\text { microlayer }\end{array}$} & BAC-DGGE-2 & $\begin{array}{l}\text { Uncultured clone } \\
\text { (AY053477) }\end{array}$ & 99 & Marine & Betaproteobacteria & Lanoil et al. (2001) \\
\hline & BAC-DGGE-3 & $\begin{array}{l}\text { Pseudomonas sp. } \\
\text { BWDY-44 (DQ314546) }\end{array}$ & 98 & Estuary & Gammaproteobacteria & Unpublished \\
\hline & BAC-DGGE-4 & $\begin{array}{l}\text { Uncultured DGGE } \\
\text { band (AJ583816) }\end{array}$ & 96 & Marine & Bacteroidetes & Unpublished \\
\hline & BAC-DGGE-10 & $\begin{array}{l}\text { Uncultured clone } \\
\text { (AY062127) }\end{array}$ & 91 & Wastewater & Betaproteobacteria & Zilles et al. (2002) \\
\hline \multirow[t]{6}{*}{$\begin{array}{l}\text { Ubiquitous } \\
\text { phylotypes }\end{array}$} & BAC-DGGE-1 & $\begin{array}{l}\text { Uncultured clone } \\
\text { (AY830016) }\end{array}$ & 98 & Marine & Bacteroidetes & Unpublished \\
\hline & BAC-DGGE-5 & $\begin{array}{l}\text { DGGE band } \\
\text { (Alteromonas sp.) } \\
\text { (AF466898) }\end{array}$ & 100 & Marine & Gammaproteobacteria & Winter et al. (2001) \\
\hline & BAC-DGGE-6 & $\begin{array}{l}\text { Glaciecola sp. WHOI } \\
\text { JT-6b (AY349463) }\end{array}$ & 98 & Marine & Gammaproteobacteria & Tolli (2003) \\
\hline & BAC-DGGE-7 & $\begin{array}{l}\text { Ruegeria sp. SC15 } \\
\text { (DQ001317) }\end{array}$ & 92 & Marine & Alphaproteobacteria & Anand et al. (2006) \\
\hline & BAC-DGGE-8 & $\begin{array}{l}\text { Uncultured clone } \\
\text { (DQ450187) }\end{array}$ & 95 & Marine & Alphaproteobacteria & Piccini et al. (2006) \\
\hline & BAC-DGGE-9 & $\begin{array}{l}\text { Uncultured clone } \\
\text { (AY828401) }\end{array}$ & 91 & Marine & Alphaproteobacteria & Unpublished \\
\hline \multirow[t]{6}{*}{$\begin{array}{l}\text { Surface } \\
\text { microlayer }\end{array}$} & ARC-DGGE-2 & $\begin{array}{l}\text { Uncultured clone } \\
\text { (DQ424907) }\end{array}$ & 98 & Marine & Crenarchaeota & Unpublished \\
\hline & ARC-DGGE-11 & $\begin{array}{l}\text { Uncultured clone } \\
\text { (DQ129987) }\end{array}$ & 93 & $\begin{array}{l}\text { Hypersaline } \\
\text { Lake }\end{array}$ & Not known & Jiang et al. (2006) \\
\hline & ARC-DGGE-7 & $\begin{array}{l}\text { Uncultured clone } \\
\text { (DQ190066) }\end{array}$ & 96 & $\begin{array}{l}\text { Freshwater } \\
\text { aquifer }\end{array}$ & Not known & Unpublished \\
\hline & ARC-DGGE-1 & $\begin{array}{l}\text { Uncultured clone } \\
\text { (AY627472) }\end{array}$ & 97 & Marine & Not known & Unpublished \\
\hline & ARC-DGGE-12 & $\begin{array}{l}\text { Uncultured clone } \\
\text { (AY396004) }\end{array}$ & 96 & $\begin{array}{l}\text { Estuarine } \\
\text { sediment }\end{array}$ & Not known & Roling et al. (2004) \\
\hline & ARC-DGGE-5 & $\begin{array}{l}\text { Uncultured clone } \\
\text { (DQ190066) }\end{array}$ & 96 & $\begin{array}{l}\text { Freshwater } \\
\text { aquifer }\end{array}$ & Not known & Unpublished \\
\hline \multirow[t]{6}{*}{$\begin{array}{l}\text { Ubiquitous } \\
\text { phylotypes }\end{array}$} & ARC-DGGE-3 & $\begin{array}{l}\text { Uncultured clone } \\
\text { (AF180687) }\end{array}$ & 98 & Estuary & Crenarchaeota & Crump and Baross (2000) \\
\hline & ARC-DGGE-4 & $\begin{array}{l}\text { Uncultured clone } \\
\text { (AF355964) }\end{array}$ & 97 & Marine & Crenarchaeota & Huber et al. (2002) \\
\hline & ARC-DGGE-6 & $\begin{array}{l}\text { Uncultured clone } \\
\text { (U78195) }\end{array}$ & 98 & Marine & Crenarchaeota & Massana et al. (1997) \\
\hline & ARC-DGGE-8 & $\begin{array}{l}\text { Uncultured clone } \\
\text { (AF355942) }\end{array}$ & 92 & Marine & Not known & Huber et al. (2002) \\
\hline & ARC-DGGE-9 & $\begin{array}{l}\text { Uncultured clone } \\
\text { (AF223131) }\end{array}$ & 90 & Marine & Euryarchaeota & Massana et al. (2000) \\
\hline & ARC-DGGE-10 & $\begin{array}{l}\text { Uncultured clone } \\
\text { (AY627472) }\end{array}$ & 96 & Marine & Not known & Unpublished \\
\hline
\end{tabular}

Abbreviations: BLAST, Basic Local Alignment Search Tool; DGGE, denaturing gradient gel electrophoresis.

(bacterioplankton) and SML (bacterioneuston) samples produced 35 and 31 OTUs respectively (data not shown). Some OTUs were present in both the SML and subsurface, indicating, as with DGGE experiments, that many bacteria are found in both the SML and the subsurface samples. However, most OTUs in both libraries were unique to that library, indicating that SML-specific or subsurface-specific bacterial populations were sampled from that environment. The bacterial 16S rRNA sequences from the clone libraries were dispersed over five classes of the Proteobacteria and the Bacteriodetes (Figure 2).

As with the bacterial community DGGE profiling, profiles generated from archaeal partial 16S rRNA gene amplicons were relatively similar (similarity $\geqslant 93 \%$ ) between sampling sites, suggesting that the subsurface (archaeaplankton) community structure changed little along the stretch of estuary sampled $(\sim 2 \mathrm{~km})$. Dominant subsurface amplicons were also dominant in the SML, yet novel amplicons were also detected in the SML (Figure 1). The habitats, where 


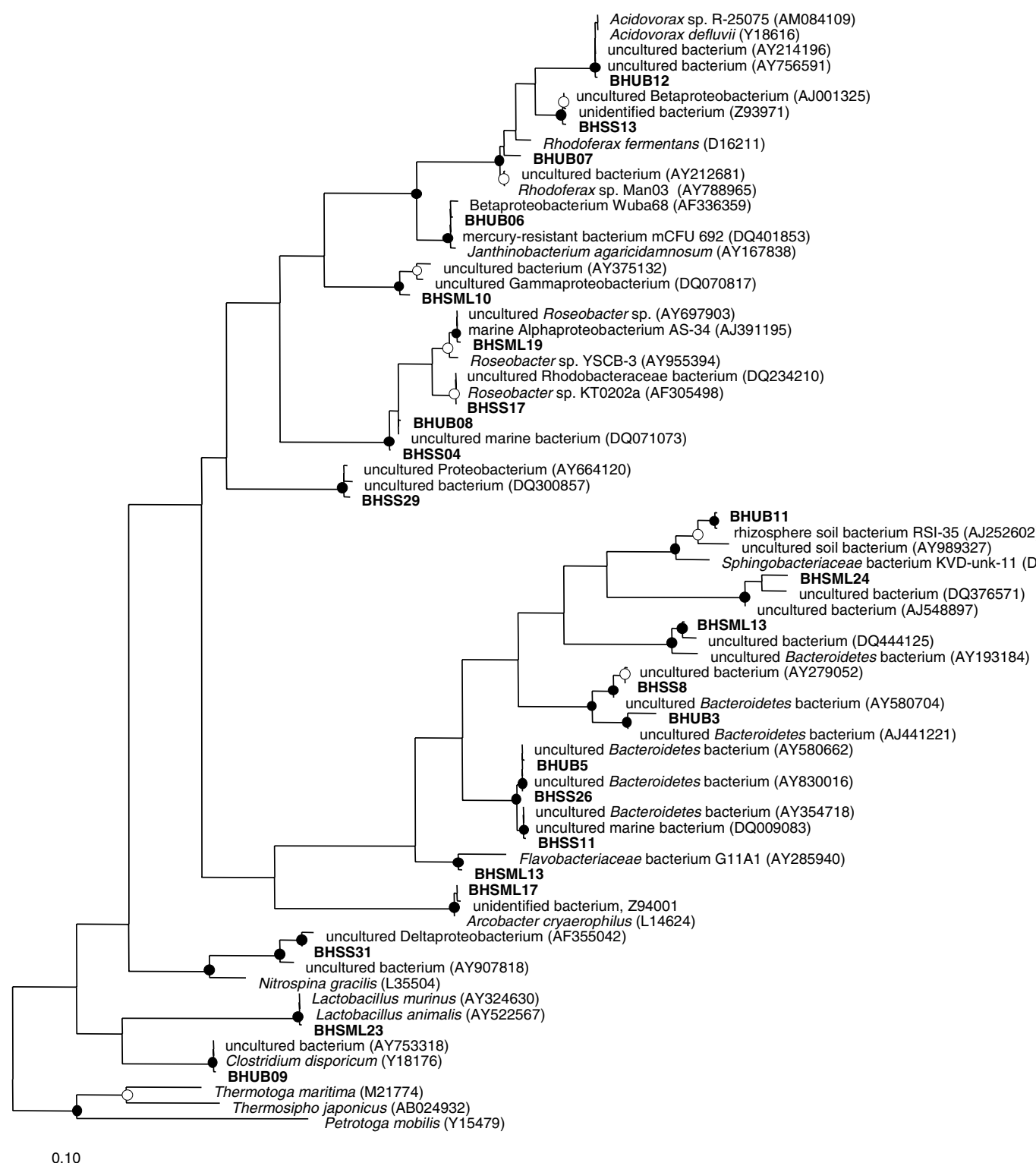

Figure 2 Phylogenetic analysis of bacterial 16S rRNA gene sequences obtained from the surface microlayer and subsurface waters ( $40 \mathrm{~cm}$ depth) of Blyth estuary and sequences available from public nucleotide databases. The tree was derived using a maximum likelihood analysis of 16S rRNA gene positions 166-626 (Escherichia coli) and the scale bar represents 10\% sequence divergence. The clone designations are as follows: UB, clones found in both the surface microlayer (SML) and the subsurface libraries; SML, found only in the SML library; and SS, found only in subsurface library. Filled circles $(\bullet)$ at branching points indicate that bootstrap values obtained by neighbour-joining analysis that were $>95 \%$; open circles $(O)$ indicate bootstrap values between $75 \%$ and $95 \%$.

closely affiliated archaeal 16S rRNA gene sequences were found, ranged from hypersaline to freshwater environments (Table 2). Many of the dominant archaeal 16S rRNA gene DGGE bands found in the subsurface and SML, assumed here as dominant populations in situ, were affiliated with known marine Crenarchaeota, with only one DGGE band being affiliated with known marine Euryarchaeota. One of the dominant archaeal populations detected in the Blyth River estuary (ARC-DGGE-3) was closely affiliated (98\% sequence similarity) to a clone detected in the Columbia River estuary, USA (Crump and Baross, 2000).
Functional gene diversity of trace gas-utilizing bacteria Bacteria have a significant involvement in the biogeochemical cycling of gases, including $\mathrm{CH}_{4}$ and CO. PCR primers targeting genes encoding subunits of pmoA, mmoX and coxL (Table 1) were used with template DNA extracted from the SML and subsurface of the two sampling sites on the Blyth estuary.

A PCR product for $p m o A$ was only obtained with DNA from the subsurface at sampling site 2 after two rounds of PCR (total 70 cycles). PCR products for mmoX genes were detected in the SML of site 1 and in both the subsurface and SML at site 2. The need 

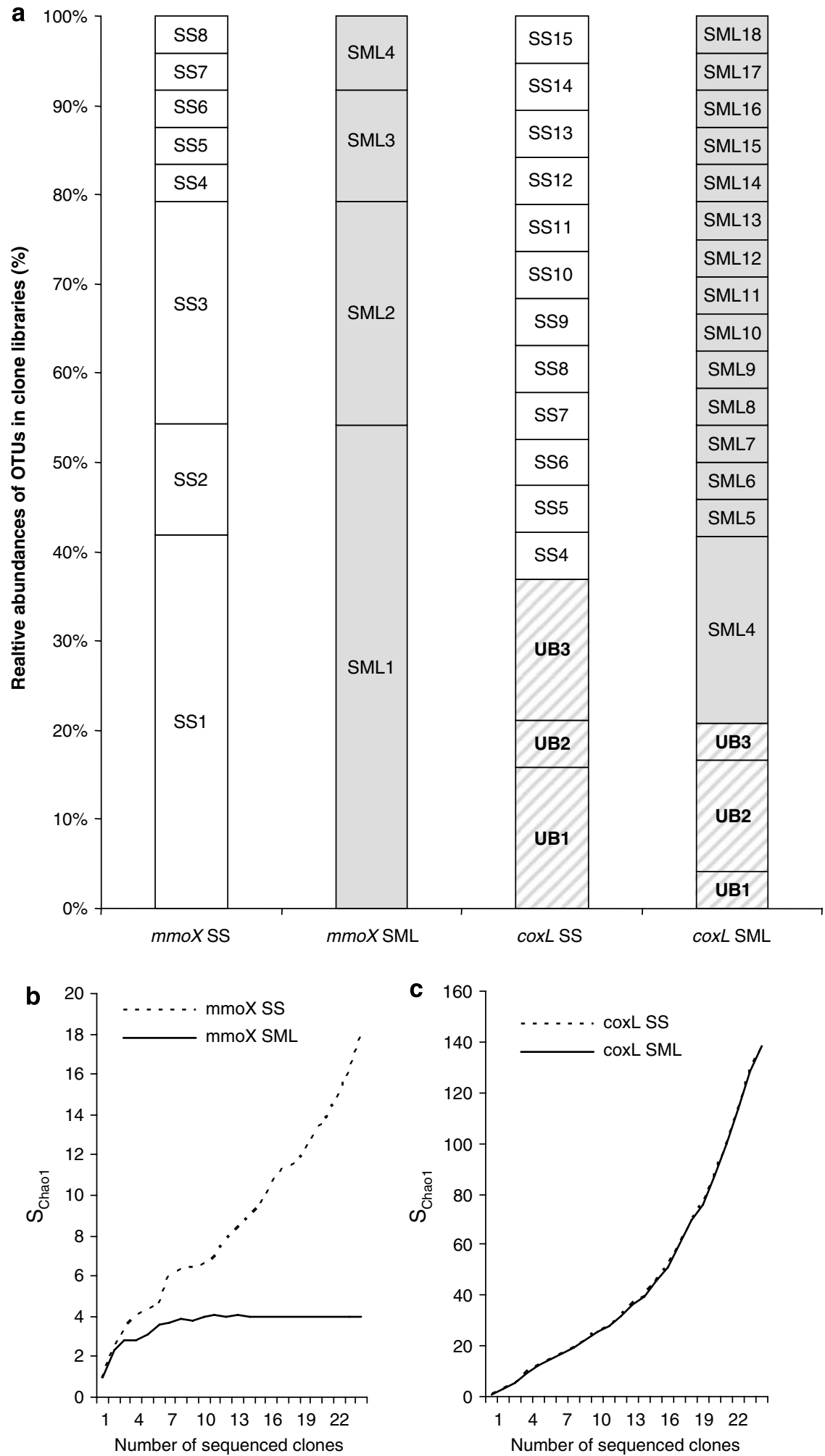

Figure 3 (a) Relative abundances of operational taxonomic units (OTUs) created from restriction fragment length polymorphism (RFLP) banding patterns of bacterial soluble methane monooxygenase $(\mathrm{mmoX})$ and carbon monoxide dehydrogenase (coxL) subunit-encoding genes. Clone libraries created from DNA extracted from the subsurface (SS, white) and surface microlayer (SML, grey) at sampling site 2 on the Blyth estuary. Hatched segments show ubiquitous OTUs (UB) that were present in both SML and subsurface DNA samples. Selected clones from the RFLP analysis were sequenced and these sequences were compared to gene sequences from extant Bacteria (Figures 4 and 5). (b and c) Rarefaction curves for mmoX and coxL libraries calculated using the nonparametric richness estimator, $S_{\text {Chao1 }}$. 
for two rounds of PCR to detect pmoA suggests that there were low numbers of methanotrophs present in the Blyth SML. Conversely, coxL genes were detected in all samples after one round of PCR (35 cycles), indicating the ubiquity and higher abundance of CO utilizers in the Blyth River estuary.

We used the nonparametric richness estimator, $S_{\text {Chao1 }}$, to determine coverage of both the mmoX and coxL gene clone libraries (Figures $3 \mathrm{~b}$ and $\mathrm{c}$ ). These data suggest that the total diversity of $\mathrm{mmoX}$ genes present in the SML is considerably less compared to the subsurface water as the rarefaction curve calculated for the SML is asymptotic. Diversity was higher in the subsurface due to the presence of several OTUs with only single representatives in the clone libraries. Rarefaction curves calculated for the coxL gene clone libraries indicates a very high diversity of this gene in both samples compared to the mmoX gene clone libraries. This is because in both libraries most OTUs were represented by single RFLPs.

mmoX clone libraries were made using PCR products from site 2 subsurface and SML samples. Results from RFLP analysis were markedly different for $m m o X$ genes in the subsurface compared to the SML. All of the mmoX OTUs were specific for each environment (Figures 3 and 4), indicating that different soluble methane monooxygenase (sMMO)containing methanotrophic communities were present in the SML compared to the corresponding subsurface samples. The $m m o X$ sequence identification indicated the dominance of Methylomonas/ Methylococcus-related methanotrophs in the samples taken, from both the subsurface water and SML (Figures 3 and 4 ).

The diversity of $p m o A$ gene sequences retrieved from the subsurface water at site 2 was very low with only three OTUs being present. The clone library RFLP analysis revealed one major OTU ( $88 \%$ of clone library) with closest sequence similarity to a known Methylobacter pmoA gene sequence (AAF08210) (Costello and Lidstrom, 1999). The two remaining low-abundance OTUs, both with a relative abundance of $6 \%$, were similar to $p m o A$ clones from uncultivated bacteria collected from a river plain aquifer (AAZ06139) (Erwin et al., 2005) and a sand water filter (ABC59829) (Stoecker et al., 2006).

As with the bacterial $16 \mathrm{~S}$ rRNA gene clone libraries described earlier, coxL clone libraries contained OTUs that were present in both the subsurface and SML DNA samples (Figure 3). The number of coxL gene OTUs was high relative to those of mmoX and pmoA genes and a large number of single representative OTUs were detected in the clone libraries that were detected only in either the SML or the subsurface DNA. The dominant $\operatorname{coxL}$ gene OTUs and some of the low-abundance coxL gene OTUs were sequenced and analysed. The coxL gene sequences from the SML and subsurface clustered into four main groups: Silicibacter pomeroyi type coxL form I gene sequences, Bradyrhizobium spp. type coxL form II gene sequences, Burkholderia spp. type coxL form II gene sequences and Roseobacter group type coxL form II gene sequences (Figure 5). As with the mmoX gene

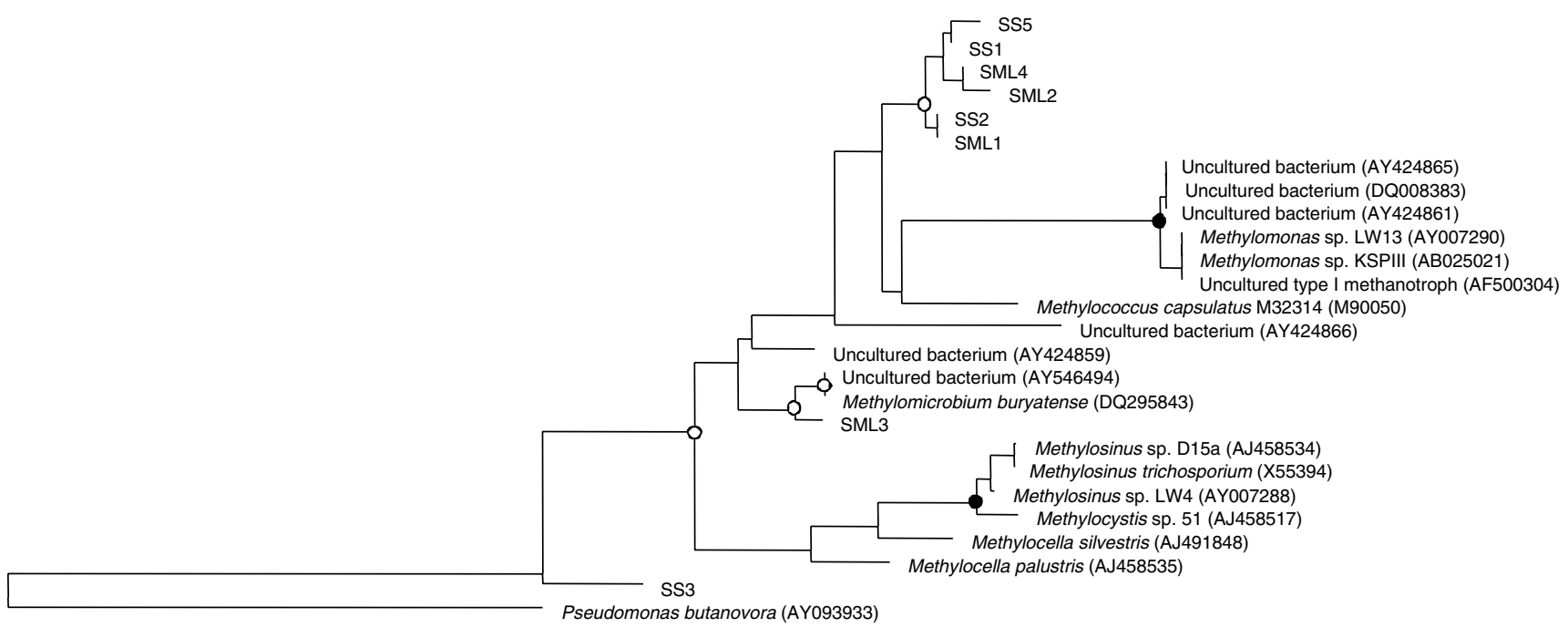

0.10

Figure 4 Phylogenetic analysis of the derived amino-acid sequences of $m m o X$ genes that encode the active-site subunit of soluble methane monooxygenase, from the Blyth estuary surface microlayer and subsurface water. The dendrogram was derived as described in Materials and methods and rooted with BmoX (soluble butane monooxygenase) from Pseudomonas butanovora (Sluis et al., 2002). The scale bar represents $10 \%$ sequence divergence. The relative abundances of Blyth estuary clones are given in Figure 3 . Filled circles $(\bullet)$ at branching points indicate that bootstrap values obtained by neighbour-joining analysis that were $>95 \%$; open circles $(\bigcirc)$ indicate bootstrap values between $75 \%$ and $95 \%$. 


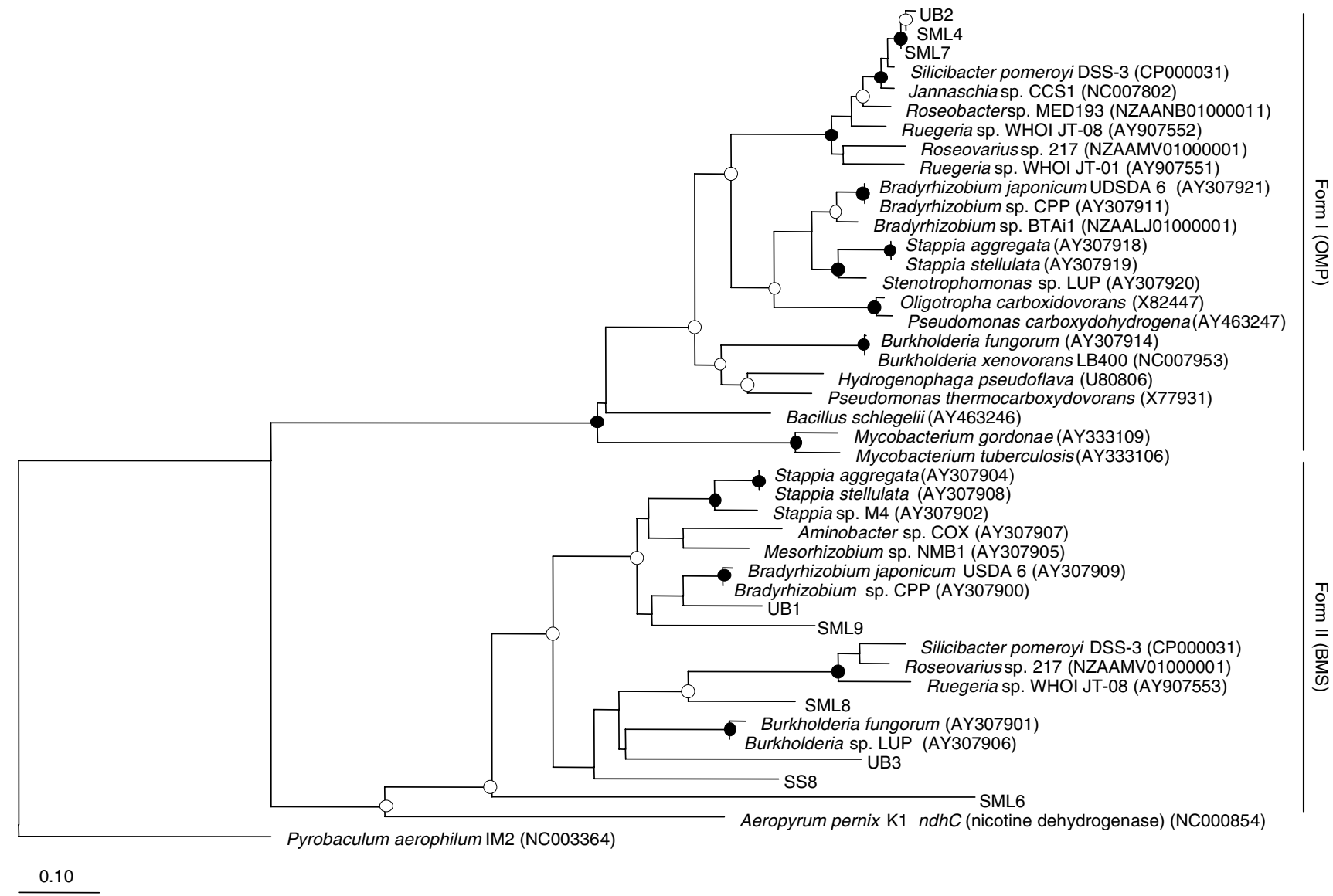

Figure 5 Phylogenetic analysis of the derived amino-acid sequences of cox $L$ genes that encode a subunit of carbon monoxide dehydrogenase from the Blyth estuary surface microlayer and subsurface water. The dendrogram was derived as described in Materials and methods and was rooted with a carbon monoxide dehydrogenase from Pyrobaculum aerophilum (NC003364). The scale bar represents $10 \%$ sequence divergence. cox $L$ genes are divided into two forms: form I (OMP represents derived cox $L$ sequences from Oligotropha, Mycobacterium, Pseudomonas) and form II (BMS represents derived coxL sequences from Bradyrhizobium, Mesorhizobium, Sinorhizobium) (King, 2003). The relative abundances of Blyth estuary clones are given in Figure 3. Filled circles (0) at branching points indicate that bootstrap values obtained by neighbour-joining analysis that were $>95 \%$; open circles $(O)$ indicate bootstrap values between $75 \%$ and $95 \%$.

sequences, coxL gene sequences found in the SML were closely related to $\operatorname{cox} L$ gene sequences found in the corresponding subsurface samples. In contrast to the methanotrophic Bacteria discussed above, the Blyth estuary has a mix of both marine and freshwater/terrestrial sequences.

\section{Discussion}

Microbial community structure and diversity

To gain insight into microbial community structure in the SML and to compare this with subsurface water, we profiled bacterial and for the first time archaeal communities using DGGE. Further analysis of bacterial diversity was made by analysis of $16 \mathrm{~S}$ rRNA gene clone libraries to make direct comparisons with previous work on the bacterioneuston of marine coastal waters (Franklin et al., 2005).

Estuaries are characterized by steep gradients in salinity and hence ionic strength, $\mathrm{pH}$, temperature and chemical composition. Each of these variables potentially impacts on microbial community structure. In the Blyth River estuary, the difference in salinity between the two sample sites had no apparent effect on microbial community structure in the subsurface water.

Bacteria and Archaea DGGE band sequences and bacterial 16S rRNA gene clone library sequences were closely associated to other sequences collected from a range of non-estuarine habitats, indicating that the microbial community present in the Blyth estuary is predominantly allochthonous (Table 2). This has also been reported for other estuarine systems; archaeal populations detected in the Columbia River system, for example, were also largely allochthonous, being associated with both terrestrial and marine sequences (Crump and Baross, 2000).

The broad range of sampling devices available to study the SML collect different SML thicknesses and therefore influence the data collected (Agogue 
et al., 2004). These include glass plates $(20-100 \mu \mathrm{m})$ (Harvey and Burzell, 1972), rotating drums (60$100 \mu \mathrm{m})$ (Harvey, 1965) and mesh screens (Garrett screen) (150-400 $\mu \mathrm{m})$ (Sieburth, 1965; Garrett, 1967). It is therefore difficult to make direct comparisons with other studies that used different sampling techniques. Franklin et al. (2005), who were the first to use polycarbonate membranes for such molecular biological studies, collected SML samples from a site in the North Sea approximately $10 \mathrm{~km}$ off the coast of Northumberland (UK), and hence in coastal waters close to the Blyth River estuary. The sampling strategy and subsequent sample processing used by Franklin et al. (2005) was almost identical to the approach used in this study (see Materials and methods). Direct comparisons can therefore be made with the bacterial 16S rRNA gene clone libraries generated by Franklin et al. (2005) and the bacterial 16S rRNA gene clone libraries generated in this study. The North Sea bacterioneuston was dominated by two groups, Vibrio spp. (68\% of clones) and Pseudoalteromonas spp. (21\% of clones). The estuarine bacterioneuston 16S rRNA gene clone library produced in this study was not dominated by any group, but instead was very diverse compared to those found in the North Sea SML (Franklin et al., 2005). High diversity is common in estuarine bacterioplankton communities, with Alphaproteobacteria, Betaproteobacteria, Gammaproteobacteria and Bacteriodetes being widespread taxa (Crump et al., 1999, 2004; Kisand and Wikner, 2003). As this study was performed on an estuary in the winter and the Franklin et al. (2005) study collected samples from an area of coastal sea in the summer, the differences in results are possibly due to differences in these two types of marine system or seasonal effects. This clearly warrants future detailed investigation.

In the Blyth estuary, microbial community structure in the SML was not the same as in subsurface water, as determined here by DGGE. Specific populations, detected as either novel DGGE bands or novel bacterial 16S rRNA gene clone library OTUs, were found only in the SML at both sampling sites. Agogue et al. (2005a) sampled the SML at two coastal stations in the Mediterranean Sea using several different sampling techniques. Single-strand conformation polymorphism analysis of the bacterioneuston and the underlying bacterioplankton at one sampling station showed very similar patterns; however, some differences were noted in community structure at the other sampling site (Agogue et al., 2005a).

16S rRNA gene sequence analysis of Bacteria and Archaea detected in the Blyth estuary showed closest homology to 16S rRNA gene sequences associated with a range of marine, estuarine and freshwater habitats. Similar results were reported for Bacteria cultivated from the Mediterranean Sea SML (Agogue et al., 2005b), indicating that populations present in the SML are found in other environments and are not exclusively neustonic. However, as only two other studies have addressed bacterial diversity in the marine SML using modern molecular techniques (Franklin et al., 2005; Agogue et al., 2005b) and no other study has addressed Archaea diversity in the SML, the existence of SML-specific populations cannot be dismissed. Indeed, the freshwater bacterium Nevskia ramosa is found in the freshwater SML and has niche adaptations for the neustonic environment (Sturmeyer et al., 1998; Pladdies et al., 2004)

Interestingly, in our study, a Crenarchaeota population was detected with its closest known affiliate having previously been found in an estuary in the United States (Crump and Baross, 2000). Recent studies have suggested that mesophilic Crenarchaeota are involved in nitrification by performing ammonia oxidation particularly in estuarine environments (Francis et al., 2005; Beman and Francis, 2006). A functional role for the Crenarchaeota was not determined in this study; however, since SML-specific populations were detected, future work will try to establish a functional role for populations of archaea in the SML.

\section{Bacterial functional gene diversity}

In this study, the pmoA and mmoX genes that were retrieved were most closely related to known freshwater methanotroph gene sequences. Several marine methanotrophs have been isolated that were identified as Methylomonas pelagica and Methylobacter marinus (Sieburth et al., 1987, 1993; Fuse et al., 1998) but none was detected in this study. Sieburth et al. (1993) used M. pelagica-targeted antisera to identify methanotrophs in $\mathrm{CH}_{4}$-enriched estuarine (Chesapeake Bay) and ocean (Sargasso Sea) water. From the ocean enrichments, $96 \%$ of the isolates were identical to $M$. pelagica; however, none of the estuarine methanotrophs was identical to M. pelagica (Sieburth et al., 1993). The estuarine mmoX sequences from this study were related to those retrieved from a freshwater lake (AF500304 and AY007290) (Auman et al., 2000; Auman and Lidstrom, 2002) suggesting that sMMO-containing methanotroph recruitment into the estuary comes via freshwater inputs. The $\operatorname{mmoX}$ gene sequences from the Blyth River estuary form a distinct clade when compared to extant sequences, suggesting the presence of estuarine-specific methanotroph communities. Similar results have also been shown for mesotrophic freshwater lake sediment, with sMMOcontaining Methylomonas type being the dominant methanotroph populations (Auman and Lidstrom, 2002). It is important to consider that there are very few data available concerning marine methanotroph diversity and gene sequences. Therefore, caution is required when interpreting data.

The potential presence of sMMO-containing methanotrophs in the Blyth estuary SML and 
subsurface water may also have wider implications other than $\mathrm{CH}_{4}$ oxidation, since the SML is known to be enriched with organic pollutants (Wurl and Obbard, 2004) and sMMO is effective at co-oxidizing halogenated organic pollutants such as trichloroethylene (Hanson and Hanson, 1996).

As with $\operatorname{mmoX}$, the $p m o A$ sequences obtained were most similar to $p m o A$ clones retrieved from the freshwater environment (Costello and Lidstrom, 1999), further suggesting that estuarine methanotroph communities develop by colonization of freshwater methanotrophs. The diversity of $p m o A$ genes recovered in this study was low, with only three OTUs being detected. Methanotroph diversity in estuarine sediments from Newport Bay in California, determined using $p m o A$ as a marker, suggested that distinct estuarine-specific communities were present (McDonald et al., 2005). We did not observe estuarine-specific $p m o A$ sequences in the bacterioplankton of this study. The diversity of pmoA gene sequences in Newport Bay sediment was greater than the diversity shown here for the Blyth estuary. However, Methylobacter pmoA gene sequences were also found to be prevalent in Newport Bay sediment (McDonald et al., 2005) as reported here for the Blyth estuary bacterioplankton.

There was a higher diversity of $\operatorname{cox} L$ sequences in both the SML and subsurface water. The use of $\operatorname{cox} L$ as a marker for CO-oxidizing Bacteria can however be problematic for two reasons: (1) sequences may be homologous to other genes for example, nicotine dehydrogenase; (2) many coxL genes present in GenBank are from genome sequences of bacteria that have not yet been proven to be CO utilizers (King, 2003; Cleave, 2005). Only three coxL OTUs were detected in both the SML and subsurface water. A high proportion of bacterioneuston $\operatorname{cox} L$ sequences detected were similar to coxL from $S$. pomeroyi, a known marine CO oxidizer (Moran et al., 2004). S. pomeroyi is part of the Roseobacter lineage, a physiologically diverse group of Alphaproteobacteria that forms a numerically significant component of marine microbial communities (Buchan et al., 2005; Wagner-Döbler and Biebl, 2006). The Roseobacter group has been shown to be responsible for a large amount of $\mathrm{CO}$ oxidation in coastal marine waters (Tolli et al., 2006). Other coxL sequences in both the SML and subsurface were similar to those from freshwater and terrestrial Bacteria indicating that in the Blyth estuary, COoxidizing communities may arise from a range of habitats.

This study indicates that the estuarine SML is a different microbial ecosystem for some functional groups, for example, methanotrophs. Since only a limited number of SML sites have been studied in depth using molecular tools (Franklin et al., 2005; Agogue et al., 2005b), clearly, further work is needed to determine the importance of bacteria that metabolize atmospheric trace gases in this distinct environment. Further work is needed to address the importance of spatiality on microbial communities in the SML at a broad range of local, regional and global scales. Furthermore, since the SML may be strongly influenced by diurnal cycles, future work will need to address temporal dynamics of SML communities.

\section{Acknowledgements}

We thank the crew of the RV Bernicia and Matt Salter from the University of Newcastle-upon-Tyne for their help with sample collection. We also thank Graeme Nicol (University of Aberdeen), Andrew Weightman and Louise O'Sullivan (Cardiff University) for helpful advice with DGGE for archaeal genes. This work was supported by the Natural Environment Research Council (NE/C001923/1) through the NERC-SOLAS thematic programme, part of the SOLAS (Surface Ocean-Lower Atmosphere Study) international research initiative.

\section{References}

Agogue H, Casamayor EO, Bourrain M, Obernosterer I, Joux F, Herndl GJ et al. (2005a). A survey on bacteria inhabiting the sea surface microlayer of coastal ecosystems. FEMS Microbiol Ecol 54: 269-280.

Agogue H, Casamayor EO, Joux F, Obernosterer I, Dupuy C, Lantoine F et al. (2004). Comparison of samplers for the biological characterization of the sea surface microlayer. Limnol Oceanogr Meth 2: 213-225.

Agogue H, Joux F, Obernosterer I, Lebaron P. (2005b). Resistance of marine bacterioneuston to solar radiation. Appl Environ Microbiol 71: 5282-5289.

Altschul SF, Gish W, Miller W, Myers EW, Lipman DJ. (1990). Basic local alignment search tool. J Mol Biol 215: 403-410.

Anand TP, Bhat AW, Shouche YS, Roy U, Siddharth J, Sarma SP. (2006). Antimicrobial activity of marine bacteria associated with sponges from the waters off the coast of South East India. Microbiol Res 161: $252-262$.

Auman AJ, Lidstrom ME. (2002). Analysis of sMMOcontaining type I methanotrophs in Lake Washington sediment. Environ Microbiol 4: 517-524.

Auman AJ, Stolyar S, Costello AM, Lidstrom ME. (2000). Molecular characterization of methanotrophic isolates from freshwater lake sediment. Appl Environ Microbiol 66: 5259-5266.

Bange HW, Bartell UH, Rapsomanikis S, Andreae MO. (1994). Methane in the Baltic and North Seas and a reassessment of the marine emissions of methane. Global Biogeochem Cy 8: 465-480.

Beman JM, Francis CA. (2006). Diversity of ammoniaoxidizing archaea and bacteria in the sediments of a hyper-nutrified subtropical estuary: Bahia del Tobari, Mexico. Appl Environ Microbiol 72: 7767-7777.

Buchan A, Gonzalez JM, Moran MA. (2005). Overview of the marine Roseobacter lineage. Appl Environ Microbiol 71: 5665-5677.

Cleave S. (2005). The Molecular Ecology of Carbon Monoxide Utilising Bacteria. PhD Thesis, Department of Biological Sciences, University of Warwick, Coventry, UK. 
Conrad R, Seiler W. (1988). Influence of the surface microlayer on the flux of nonconservative trace gases (CO, $\mathrm{H}_{2}, \mathrm{CH}_{4}, \mathrm{~N}_{2} \mathrm{O}$ ) across the ocean-atmosphere interface. J Atmos Chem 6: 83-94.

Costello AM, Lidstrom ME. (1999). Molecular characterization of functional and phylogenetic genes from natural populations of methanotrophs in lake sediments. Appl Environ Microbiol 65: 5066-5074.

Crump BC, Armbrust EV, Baross JA. (1999). Phylogenetic analysis of particle-attached and free-living bacterial communities in the Columbia River, its estuary, and the adjacent coastal ocean. Appl Environ Microbiol 65: 3192-3204.

Crump BC, Baross JA. (2000). Archaeaplankton in the Columbia River, its estuary and the adjacent coastal ocean, USA. FEMS Microbiol Ecol 31: 231-239.

Crump BC, Hopkinson CS, Sogin ML, Hobbie JE. (2004). Microbial biogeography along an estuarine salinity gradient: combined influences of bacterial growth and residence time. Appl Environ Microbiol 70: 1494-1505.

Crutzen PJ. (1991). Atmospheric chemistry-methanes sinks and sources. Nature 350: 380-381.

Cunliffe M, Kertesz MA. (2006). Effect of Sphingobium yanoikuyae B1 inoculation on bacterial community dynamics and polycyclic aromatic hydrocarbon degradation in aged and freshly $\mathrm{PAH}$-contaminated soils. Environ Pollut 144: 228-237.

DeLong EF. (1992). Archaea in coastal marine environments. Proc Natl Acad Sci USA 89: 5685-5689.

Dlugokencky EJ, Masarie KA, Lang PM, Tans PP. (1998). Continuing decline in the growth rate of the atmospheric methane burden. Nature 393: 447-450.

Dlugokencky EJ, Walter BP, Masarie KA, Lang PM, Kasischke ES. (2001). Measurements of an anomalous global methane increase during 1998. Geophys Res Lett 28: 499-502.

Dumont MG, Murrell JC. (2005). Community-level analysis: key genes of aerobic methane oxidation. Methods Enzymol 397: 413-427.

Dunfield KE, King GM. (2004). Molecular analysis of carbon monoxide-oxidizing bacteria associated with recent Hawaiian volcanic deposits. Appl Environ Microbiol 70: 4242-4248.

Dunfield KE, King GM. (2005). Analysis of the distribution and diversity in recent Hawaiian volcanic deposits of a putative carbon monoxide dehydrogenase large subunit gene. Environ Microbiol 7: 1405-1412.

Erwin DP, Erickson IK, Delwiche ME, Colwell FS, Strap JL, Crawford RL. (2005). Diversity of oxygenase genes from methane- and ammonia-oxidizing bacteria in the Eastern Snake River Plain aquifer. Appl Environ Microbiol 71: 2016-2025.

Felsenstein J. (1993). PHYLIP (Phylogeny Inference Package) Version 3.5c. Distributed by the author Department of Genetics, University of Washington: Seattle.

Francis CA, Roberts KJ, Beman JM, Santoro AE, Oakley BB. (2005). Ubiquity and diversity of ammoniaoxidizing archaea in water columns and sediments of the ocean. Proc Natl Acad Sci USA 102: 14683-14688.

Franklin MP, McDonald IR, Bourne DG, Owens NJ, Upstill-Goddard RC, Murrell JC. (2005). Bacterial diversity in the bacterioneuston (sea surface microlayer): the bacterioneuston through the looking glass. Environ Microbiol 7: 723-736.
Fuse H, Ohta M, Takimura O, Murakami K, Inoue $\mathrm{H}$, Yamaoka $\mathrm{Y}$ et al. (1998). Oxidation of trichloroethylene and dimethyl sulfide by a marine Methylomicrobium strain containing soluble methane monooxygenase. Biosci Biotechnol Biochem 62: 1925-1931.

Garrett WD. (1967). The organic chemical composition of the ocean surface. Deep Sea Res 14: 221-227.

Hanson RS, Hanson TE. (1996). Methanotrophic bacteria. Microbiol 60: 429-471.

Harvey GW. (1965). Microlayer collection from the sea surface. A new method and initial results. Limnol Oceanogr 11: 608-613.

Harvey GW, Burzell LA. (1972). A simple microlayer method for small samples. Limnol Oceanogr 11: 156-157.

Holmes AJ, Owens NJP, Murrell JC. (1995). Detection of novel marine methanotrophs using phylogenetic and functional gene probes after methane enrichment. Microbiology-UK 141: 1947-1955.

Horz HP, Raghubanshi AS, Heyer E, Kammann C, Conrad R, Dunfield PF. (2002). Activity and community structure of methane-oxidising bacteria in a wet meadow soil. FEMS Microbiol Ecol 41: 247-257.

Huber JA, Butterfield DA, Baross JA. (2002). Temporal changes in archaeal diversity and chemistry in a midocean ridge subseafloor habitat. Appl Environ Microbiol 68: 1585-1594.

Hutchens E, Radajewski S, Dumont MG, McDonald IR, Murrell JC. (2004). Analysis of methanotrophic bacteria in Movile Cave by stable isotope probing. Environ Microbiol 6: 111-120.

IPCC. (2001). Climate Change 2001. Geneva: Switzerland.

Jurgens G, Lindstrom K, Saano A. (1997). Novel group within the kingdom crenarchaeota from boreal forest soil. Appl Environ Microbiol 63: 803-805.

King GM. (2003). Molecular and culture-based analyses of aerobic carbon monoxide oxidizer diversity. Appl Environ Microbiol 69: 7257-7265.

King GM, Weber CF. (2007). Distribution, diversity and ecology of aerobic CO-oxidizing bacteria. Nat Rev Microbiol 5: 107-118.

Kisand V, Wikner J. (2003). Combining culture-dependent and -independent methodologies for estimation of richness of estuarine bacterioplankton consuming riverine dissolved organic matter. Appl Environ Microbiol 69: 3607-3616.

Kolb S, Knief C, Stubner S, Conrad R. (2003). Quantitative detection of methanotrophs in soil by novel pmoAtargeted real-time PCR assays. Appl Environ Microbiol 69: $2423-2429$.

Lane DJ. (1991). 16S/23S rRNA sequencing. In: Stackebrandt E, Goodfellow M (eds). Nucleic Acid Techniques in Bacterial Systematics. John Wiley \& Sons: Chichester, UK, pp 115-175.

Lanoil BD, Sassen R, La Duc MT, Sweet ST, Nealson KH (2001). Bacteria and Archaea physically associated with Gulf of Mexico gas hydrates. Appl Environ Microbiol 67: 5143-5153.

Lee SM, Chao A. (1994). Estimating population size via sample coverage for closed capture-recapture models. Biometrics 50: 88-97.

Lelieveld J, Crutzen PJ, Dentener FJ. (1998). Changing concentration, lifetime and climate forcing of atmospheric methane. Tellus Chem Phys Meteorol 50: $128-150$. 
Liss PS, Duce RA (eds). (1997). The Sea Surface and Global Change, Vol. Cambridge University Press: UK.

Ludwig W, Strunk O, Klugbauer S, Klugbauer N, Weizenegger M, Neumaier J et al. (1998). Bacterial phylogeny based on comparative sequence analysis. Electrophoresis 19: 554-568.

Massana R, DeLong EF, Pedros-Alio C. (2000). A few cosmopolitan phylotypes dominate planktonic archaeal assemblages in widely different oceanic provinces. Appl Environ Microbiol 66: 1777-1787.

Massana R, Murray AE, Preston CM, DeLong EF. (1997). Vertical distribution and phylogenetic characterization of marine planktonic Archaea in the Santa Barbara Channel. Appl Environ Microbiol 63: 50-56.

McDonald IR, Smith K, Lidstrom ME. (2005). Methanotrophic populations in estuarine sediment from Newport Bay, California. FEMS Microbiol Lett 250: 287-293.

Monson RK, Holland EA. (2001). Biospheric trace gas fluxes and their control over tropospheric chemistry. Annu Rev Ecol Systemat 32: 547-576.

Moran MA, Buchan A, Gonzalez JM, Heidelberg JF, Whitman WB, Kiene RP et al. (2004). Genome sequence of Silicibacter pomeroyi reveals adaptations to the marine environment. Nature 432: 910-913.

Mudryk ZJ. (2002). Antibiotic resistance among bacteria inhabiting surface and subsurface water layers in estuarine lake Gardno. Pol J Environ Stud 11: 401-406.

Mudryk ZJ, Skorczewski P. (2000). Occurrence and activity of lipolytic bacterioneuston and bacterioplankton in the estuarine Lake Gardno. Estuar Coast Shelf Sci 51: 763-772.

Murray AE, Preston CM, Massana R, Taylor LT, Blakis A, Wu K et al. (1998). Seasonal and spatial variability of bacterial and archaeal assemblages in the coastal waters near Anvers Island, Antarctica. Appl Environ Microbiol 64: 2585-2595.

Muyzer G, de Waal EC, Uitterlinden AG. (1993). Profiling of complex microbial populations by denaturing gradient gel electrophoresis analysis of polymerase chain reaction-amplified genes coding for $16 \mathrm{~S}$ rRNA. Appl Environ Microbiol 59: 695-700.

Nicol GW, Glover LA, Prosser JI. (2003). The impact of grassland management on archaeal community structure in upland pasture rhizosphere soil. Environ Microbiol 5: 152-162.

Ovreas L, Forney L, Daae FL, Torsvik V. (1997). Distribution of bacterioplankton in meromictic Lake Saelenvannet, as determined by denaturing gradient gel electrophoresis of PCR-amplified gene fragments coding for $16 \mathrm{~S}$ rRNA. Appl Environ Microbiol 63: 3367-3373.

Piccini C, Conde D, Alonso C, Sommaruga R, Pernthaler J. (2006). Blooms of single bacterial species in a coastal lagoon of the southwestern Atlantic Ocean. Appl Environ Microbiol 72: 6560-6568.

Pladdies T, Babenzien HD, Cypionka H. (2004). Distribution of Nevskia ramosa and other rosette-forming neustonic bacteria. Microb Ecol 47: 218-223.

Roling WF, de Brito Couto IR, Swannell RP, Head IM. (2004). Response of Archaeal communities in beach sediments to spilled oil and bioremediation. Appl Environ Microbiol 70: 2614-2620.

Sieburth JM. (1965). Bacteriological samples for airwater and water-sediment interfaces. Ocean science and Ocean engineering. In: Transactions of the
Joint Conference, MTS and ASLO. Washington, DC, pp 1064-1068.

Sieburth JM, Johnson PW, Church VM, Laux DC. (1993). C1 bacteria in the water column of Chesapeake Bay, USA.3. Immunological relationships of the type species of marine monomethylamine-oxidizing and methane-oxidizing bacteria to wild estuarine and oceanic cultures. Mar Ecol Progr 95: 91-102.

Sieburth JM, Johnson PW, Eberhardt MA, Sieracki ME, Lidstrom M, Laux D. (1987). The 1st methane-oxidizing bacterium from the upper mixing layer of the deep ocean-Methylomonas pelagica sp nov. Curr Microbiol 14: 285-293.

Sluis MK, Sayavedra-Soto LA, Arp DJ. (2002). Molecular analysis of the soluble butane monooxygenase from 'Pseudomonas butanovora'. Microbiology 148: 3617-3629.

Somerville CC, Knight IT, Straube WL, Colwell RR. (1989). Simple, rapid method for direct isolation of nucleic acids from aquatic environments. Appl Environ Microbiol 55: 548-554.

SpringerYoung M, Erickson DJ, Carsey TP. (1996). Carbon monoxide gradients in the marine boundary layer of the North Atlantic Ocean. J Geophys Res 101: 4479-4484.

Stoecker K, Bendinger B, Schoning B, Nielsen PH, Nielsen JL, Baranyi C et al. (2006). Cohn's Crenothrix is a filamentous methane oxidizer with an unusual methane monooxygenase. Proc Natl Acad Sci USA 103: $2363-2367$.

Stubbins A. (2001). Aspects of aquatic CO photoproduction from CDOM. PhD Thesis, University of Newcastle-upon-Tyne, Newcastle-upon-Tyne.

Sturmeyer H, Overmann J, Babenzien HD, Cypionka H. (1998). Ecophysiological and phylogenetic studies of Nevskia ramosa in pure culture. Appl Environ Microbiol 64: 1890-1894.

Tolli JD. (2003). Identity and dynamics of the microbial community responsible for carbon monoxide oxidation in marine environments. $\mathrm{PhD}$ Thesis, Woods Hole Oceanographic Institute, Woods Hole, MA, USA.

Tolli JD, Sievert SM, Taylor CD. (2006). Unexpected diversity of bacteria capable of carbon monoxide oxidation in a coastal marine environment, and contribution of the Roseobacter-associated clade to total CO oxidation. Appl Environ Microbiol 72: 1966-1973.

Upstill-Goddard RC, Barnes J, Frost T, Punshon S, Owens NJP. (2000). Methane in the southern North Sea: low-salinity inputs, estuarine removal, and atmospheric flux. Global Biogeochem $C y$ 14: 1205-1217.

Upstill-Goddard RC, Frost T, Henry GR, Franklin M, Murrell JC, Owens NJP. (2003). Bacterioneuston control of air-water methane exchange determined with a laboratory gas exchange tank. Global Biogeochem $C y$ 17: 1-15.

Wagner-Döbler I, Biebl H. (2006). Environmental biology of the marine Roseobacter lineage. Annu Rev Microbiol 60: 255-280.

Whittenbury R, Phillips KC, Wilkinson JF. (1970). Enrichment, isolation and some properties of methane-utilizing bacteria. J Gen Microbiol 61: 205-218.

Winter C, Moeseneder MM, Herndl GJ. (2001). Impact of UV radiation on bacterioplankton community composition. Appl Environ Microbiol 67: 665-672. 
Wurl O, Obbard JP. (2004). A review of pollutants in the sea-surface microlayer (SML): a unique habitat for marine organisms. Mar Pollut Bull 48: 1016-1030.

Xie HX, Zafiriou OC, Umile TP, Kieber DJ. (2005). Biological consumption of carbon monoxide in Delaware Bay, NW Atlantic and Beaufort Sea. Mar Ecol Progr 290: 1-14.

Zhang Z, Liu L, Liu C, Cai W. (2003). Studies on the sea surface microlayer. II. The layer of sudden change of physical and chemical properties. J Colloid Interface Sci 264: 148-159.

Zhang ZB, Liu LS, Wu ZJ, Li J, Ding HB. (1998). Physicochemical studies of the sea surface microlayer-I. Thickness of the sea surface microlayer and its experimental determination. J Colloid Interface Sci 204: 294-299.

Zhengbin Z, Liansheng L, Zhijian W, Jun L, Haibing D. (1998). Physicochemical studies of the sea surface microlayer. J Colloid Interface Sci 204: 294-299.

Zilles JL, Peccia J, Kim MW, Hung CH, Noguera DR. (2002). Involvement of Rhodocyclus-related organisms in phosphorus removal in full-scale wastewater treatment plants. Appl Environ Microbiol 68: 2763-2769.

Zuo Y, Jones RD. (1995). Formation of carbon-monoxide by photolysis of dissolved marine organic material and its significance in the carbon cycling of the oceans. Naturwissenschaften 82: 472-474. 